\title{
超音波照射による水中のクロロエチレン類の 分解の基礎的検討
}

\author{
趙 一先 ${ }^{1)}$, 張 大年 ${ }^{11}$, 稲津 晃司 ${ }^{2)}$, 永田 良雄 ${ }^{3)}$, \\ 竹中 規訓 ${ }^{4)}$, 坂東 博 ${ }^{4)}$, 前田 泰昭 ${ }^{4)}$ \\ ${ }^{1)}$ 中国華東理工大学環境工程研究所 (中国上海市梅隴路130号) \\ ${ }^{2)}$ 東京工業大学資源化学研究所（厂 226-0026 神奈川県横浜市緑区長津田町 4259） \\ ${ }^{3)}$ 大阪府立大学先端科学研究所 ( $5599-8531$ 大阪府堺市学園町 1-1) \\ ${ }^{4)}$ 大阪府立大学工学部（广599-8531 大阪府堺市学園町 1-1）
}

[平成11年 5 月 6 日受理 $]$

\section{Fundamental Study on the Decomposition of Chlorinated Hydrocarbons in Aqueous Solutions by Ultrasonic Irradiation}

\author{
Yi-Xian ZHAO ${ }^{1)}$, Da-Nian ZHANG ${ }^{1}$, Koji INAZU' ${ }^{2}$, Yoshio NAGATA ${ }^{3)}$, \\ Norimichi TAKENAKA ${ }^{4)}$, Hiroshi BANDOW $^{4)}$ and Yasuaki MAEDA ${ }^{4)}$ \\ ${ }^{1)}$ Institute of Environmental Engineering East China University of Science \& Technology \\ (130 Meilong Road, Shanghai 200237 P.R.China) \\ ${ }^{2}$ Research Laboratory of Resources Utilization, Tokyo Institute of Technology \\ (4259 Nagatsuda, Midori-ku, Yokohama, Kanagawa 226-0026) \\ ${ }^{3)}$ Research Institute for Advanced Science and Technology Osaka Prefecture University \\ (1-1 Gakuen-cho, Sakai, Osaka 599-8531) \\ ${ }^{4)}$ College of Engineering, Osaka Prefecture University \\ (1-1 Gakuen-cho, Sakai, Osaka 599-8531) \\ [Received May 6, 1999]

\begin{abstract}
Summary
A treatment process of the decomposition of chlorinated hydrocarbons in aqueous solution by high intensity ultrasonic irradiation has been studied. In this work, the effects of bottom thickness and volume of pyrex-glass reaction vessel, temperature, ultrasound frequency, ultrasound intensity, ultrasound oscillator and reaction atmosphere on the decomposition were investigated. Under the obtained optimum operation condition, over $80 \%$ of $10 \mathrm{ppm}$ trichloroethylene, tetrachloroethylene and 1,1,1-trichloroethane are decomposed within 10min. The major products were chloride anion, carbon monoxide, carbon dioxide and hydrogen.
\end{abstract}

Key words: Ultrasonic Irradiation, Chlorinated Hydrocarbons, Ultrasonic Degradation, Wastewater Treatment 


\section{1.はじめに}

クロロフロロカーボン（CFC）によるオゾン層の破壊 は世界的な問題になっているため, 国際的な規制が行わ れている。しかし，クロロエチレン類などの有機塩素化 合物は CFC の原料, 代替品および洗浄用溶剤として生 産量, 使用量とも微増傾向にある ${ }^{1)}$ 。これらの有機塩素 化合物は難分解性, 拡散性という大きな污染能力を持ち, 神経障害, 内臓障害, あるいは発癌性をもつものが多く, 典型的な環境污染物として大きな問題となっている2)。

近年, この有害物質の処理には, 過酸化水素と紫外線 照射, オゾン処理の組み合わせ ${ }^{3)}$, 金属鉄による還元 ${ }^{4)}$, 半導体光触媒による分解），環境適合性に優れた生物分 解昼, 超音波処理 ${ }^{7)}$ につて様々な研究が行われるよう になった。

超音波照射は用いる装置, 条件によって効率に差異が ある。本研究では, 水への高出力超音波照射によって $\mathrm{OH}$ ラジカルなどの活性種が生成することに着目し, 有 機塩素化合物の最適な分解条件の検討を行い，得られた 条件下でのクロロエチレン類の分解反応の詳細について 研究した。

\section{2．超音波照射による操作因子の影響}

\section{1 原理}

超音波とは周波数 $20 \mathrm{kHz}$ から $2 \mathrm{MHz}$ までの音波であ ると定義されている。水への超音波照射により式(1)に 示すように水の分解生成物である水素原子と $\mathrm{OH}$ ラジカ ルが生成する ${ }^{8,9)}$ 。

$$
\mathrm{H}_{2} \mathrm{O} \rightarrow \mathrm{H} \cdot+\mathrm{OH} .
$$

また，水に高出力の超音波を照射すると，超音波により 水中に気泡が生成・成長・崩壊し，その際，系内に局部 的高温・高圧状態のキャビテーションが生じる ${ }^{10)}$ 。

ここで形成されるキャビテーションバブルには二種類 のものがある。1つは, 瞬間的に崩壊する transient bubble (以下 t.b. と略記) で，もう1つは，穏やかに崩 壊する stable bubble (以下 s.b. と略記) である。t.b. は 約 $1 \sim 2 \mu \mathrm{sec}$. の寿命をもち, 内部に溶存気体をわずか に含むだけで，その溶存気体が衝突的，断熱的に崩壊す ることによって，液体分子は大きな加速度をもって互い に衝突するため, t.b. 界面は瞬間的に数千 K, 数百から数 千気圧という高温高圧状態となる。この瞬間に液体分子 の分解やラジカルの生成といった大きなエネルギーを要 する化学反応が起こる。 s.b. は約数十 $\mu$ sec. の寿命をも ち, 内部に溶存気体や溶媒や溶質液体の蒸気を含む。こ のため, 崩壊の際の液体分子衝突はやわらげられ，千数 百 $\mathrm{K}$, 数十気圧が達成されるが, 寿命が長いため化学作 用，特に加水分解などの分子の衝突が反応進行の大きな
要因である場合に非常に寄与が大きい。これらの水中に 生成する高温・高圧反応場を用いて有害物質を処理する ことができる。

\section{2 実験}

\section{2. 1 試薬}

水：イオン交換, 蒸留により精製した水をさらに，ミ リポア工業製 MILLI-Q Labo を用いて精製した超純水を 用いた。硫酸アンモニウム鉄（II）六水和物 $\left(\mathrm{Fe}\left(\mathrm{NH}_{4}\right)_{2}\right.$ $\left(\mathrm{SO}_{4}\right)_{2} \cdot 6 \mathrm{H}_{2} \mathrm{O}$, モ一儿塩): 和光純薬工業製試薬一級, 硫酸：和光純薬工業製精密分析用, 1,1-ジクロロアセ卜 ン(以下 $1,1-D C A$ と略記) : Aldrich Chemical 製, ドデ シルベンゼンスルホン酸 (ソフト型) : 東京化成工業製, インジゴカーミン, 炭酸水素ナトリウム, 炭酸ナトリウ ムと塩化ナトリウムはすべて和光純薬工業製試薬特級を 用いた。

\section{2. 2 実験装置}

実験はFig. 1 に示す装置を用いて行った。照射容器は $\phi 50 \mathrm{~mm}$ ，底面がフラットなパイレックス製のものを用 いた。恒温槽は $25 \pm 2{ }^{\circ} \mathrm{C}$, 照射位置は, 照射容器の底面 を振動子から，水中の照射した超音波波長の約半分であ る $3.8 \mathrm{~mm}$ 離した。

超音波発生装置；海上電機製（TA-4021型，200W）, 超音波発振子; 海上電機製 $4492 \mathrm{H}$ 型 $(50 \mathrm{KHz})$ と4611型 $(200 \mathrm{KHz}, 600 \mathrm{KHz})$, 温度計; 横河北辰電機製 2542 型, 紫外. 可視分光光度計; 島津製作所製 UV3100-S 型, ガ

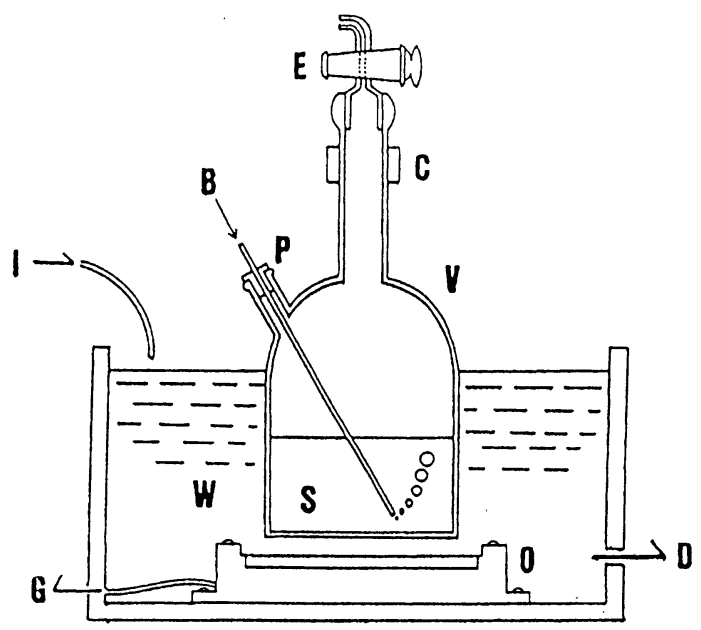

Fig. 1 Typical irradiation apparatus

$\mathrm{V}$; glass vessel, S; sample solution, O; oscillator, $\mathrm{G}$; ultrasound generator, W; cooling water, E; cock or stopper, C; clamp, P; silicone septum, $\mathrm{B}$; bubbling gas, I; cooling water inlet, D; cooling water drain 
スクロマトグラフ; 横河電機製 HP-5890A 型（TCD 付, $\mathrm{ECD}$ 付)，イオンクロマトグラフ；横河北辰電機製 IC-100型を用いた。

\section{2.3 実験操作}

（1）照射容器の底面の厚さ；0.5mm, $0.7 \mathrm{~mm}, 1.0 \mathrm{~mm}$ で ある照射容器それぞれに純水 $50 \mathrm{~g}$ を入れ, 周波数 $200 \mathrm{KHz}$, 強度 $6 \mathrm{~W} / \mathrm{cm}^{2}$ の超音波を 1 分間照射し，10秒ごとに温度 を測定し, 温度上昇をエネルギーの吸収効率の目安とし た。

（2）サンプル溶液量 ; $0.8 \mathrm{~N}$ 硫酸, $1 \mathrm{mmol} / \ell \mathrm{NaCl}, 1$ $\mathrm{mmol} / \ell \mathrm{Fe}\left(\mathrm{NH}_{4}\right)_{2}\left(\mathrm{SO}_{4}\right)_{2}$ を含んだ水溶液をそれぞれの照 射容器に $50 \mathrm{~g}, 75 \mathrm{~g}, 100 \mathrm{~g}, 125 \mathrm{~g}$ 入れ, 周波数 $200 \mathrm{KHz}$, 強度 $6 \mathrm{~W} / \mathrm{cm}^{2}$ の超音波を10分間照射した。 $\mathrm{Fe}^{2+}$ が $\mathrm{OH}$ ラ ジカルや過酸化水素によって $\mathrm{Fe}^{3+}$ に酸化させることを 利用し, $\mathrm{Fe}^{2+} \rightarrow \mathrm{Fe}^{3+}$ による304nm の吸光度の変化を紫 外 - 可視分光光度計で測定し, 生成した $\mathrm{Fe}^{3+}$ の濃度を 測定した。

（3）照射温度；照射容器に純水 $65 \mathrm{~g}$ をれ，40分間アル ゴンでバブリングし, 密栓したのち, 冷却水を $20^{\circ} \mathrm{C}$,

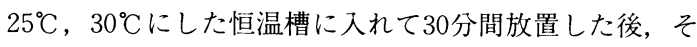
れぞれに周波数 $200 \mathrm{KHz}$, 強度 $6 \mathrm{~W} / \mathrm{cm}^{2}$ の超音波を 5 分 間照射した。容器上部の気体を $0.5 \mathrm{~m} \ell$ サンプリングし, 水素生成量を測定した。

（4）超音波の周波数による効率の変化; 照射容器に純水 $65 \mathrm{~g}$ 入れ, 40分間アルゴンでバブリングした後, 密栓し, 周波数・強度がそれぞれ $200 \mathrm{KHz}^{-} 6 \mathrm{~W} / \mathrm{cm}^{2}, 600 \mathrm{KHz}-$ $6 \mathrm{~W} / \mathrm{cm}^{2}, 50 \mathrm{KHz}-6 \mathrm{~W} / \mathrm{cm}^{2}, 200 \mathrm{KHz}-4.8 \mathrm{~W} / \mathrm{cm}^{2}, 600$ $\mathrm{kHz}-4.8 \mathrm{w} / \mathrm{cm}^{2}, 50 \mathrm{kHz}-4.8 \mathrm{w} / \mathrm{cm}^{2}$ の超音波を 10 分間照射 した後，（3）の操作と同様に水素生成量を測定した。

（5）超音波の強度による効率の変化; 照射容器に80 $\mu \mathrm{mol} / \ell$ の $1,1-\mathrm{DCA}$ 水溶液 $65 \mathrm{~g}$ を入れ, 40分間アルゴン でバブリングした後, 超音波出力強度を変化させ, 周波 数 $200 \mathrm{KHz}$ の超音波を10分間照射した後，1,1-DCA の濃 度と塩化物イオンの濃度を測定した。1,1-DCAを用い たのは,この化合物の分解速度が遅く, 1 分子の 1,1-DCA から 2 分子の塭化物イオンが生成するため, 塩化物イオンの生成量を測ることによって, その分解率 の違いを検討する事ができるので，実験がやり易いため である。

（6）照射雲囲気；照射容器に純水 $65 \mathrm{~g}$ を入，40分間ア ルゴン, 酸素, 窒素, ヘリウム, 亜酸化窒素, 空気のそ れそれでバブリングしたものに周波数 $200 \mathrm{KHz}$, 強度 6 $\mathrm{W} / \mathrm{cm}^{2}$ の超音波を10分間照射し, 水素生成量を測定した。 （7）硝酸の生成；照射容器に純水 $65 \mathrm{~g}$ を入れ４0分間ア ルゴン, 酸素でバブリングしたものおよび空気飽和にし たものそれぞれに周波数 $200 \mathrm{KHz}$, 強度 $6 \mathrm{~W} / \mathrm{cm}^{2}$ の超音 波を照射した。15分または 60 分おきに溶液 $1 \mathrm{m \ell}$ ずつを
サンプリングし，生成した亜硝酸イオンと硝酸イオンを 測定した。

（8）振動子の性能評価；性能評価法に基づき，100ppm のインジゴカーミン水溶液 $65 \mathrm{~g}$ を照射容器に入れ, 周波 数 $200 \mathrm{KHz}$ ，強度 $6 \mathrm{~W} / \mathrm{cm}^{2}$ の超音波を 40 分間照射した。 10分おきにサンプリングし，611nm の吸収の変化を紫 外・可視分光光度計で測定した。

（9）分析方法; 水素は GC-TCD で, 塩化物イオンと亜 硝酸と硝酸イオンはイオンクロマトグラフで, 1,1-DCA は GC-ECD でそれぞれの濃度を測定した。

\section{3 結果および検討}

\section{3.1 照射容器の底面の厚さ}

Fig. 2 に超音波照射による水の温度上昇の様子を示 す。底面 $0.5 \mathrm{~mm}$ の場合が最も温度上昇が大きく, $0.7 \mathrm{~mm}$ と $1.0 \mathrm{~mm}$ の厚さのものでは大きな差がなく, 底面が薄い ほどエネルギーの吸収が良くなることが分かった。しか し, 厚さの薄いものは破損しやすいため, 以後の実験で は底面 $1.0 \mathrm{~mm}$ の厚さの容器を用いることとした。

\section{3. 2 サンプル溶液量}

Fig. 3 に示したようにサンプル溶液量は少ないほうが 収率が上がることになる。溶液の絶対量が増すと, 溶液 上部では単位量当たりの超音波強度が小さくなるため, 生成する $\mathrm{Fe}^{3+}$ の絶対量が増してもその濃度は高くなら ない。また, 容器底面が平らなものの方が球状底面より 約 10 倍効率が良く ${ }^{10)}$, 液高が半波長 $(200 \mathrm{KHz}$ では3.88 $\mathrm{mm}$ ）の整数倍の時 ${ }^{11)}$ ，エネルギーの吸収率が最大とな る。これらの事から液量は $50 \mathrm{~m} \ell$ の場合が効率は良いが, サンプリング（一回当たり約 $1.4 \mathrm{~m} \ell$ ）による影響を受け ないことから, 照射時に用いる試料溶液量を $65 \mathrm{~g}$ とした。

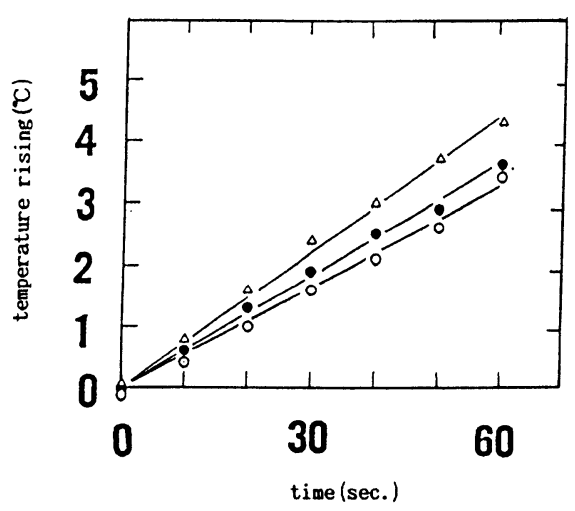

Fig. 2 Effect of bottom plate thickness on energy absorption in the ultrasonic irradiation of water
$\bigcirc ; 1 \mathrm{~mm}, \quad ; 0.7 \mathrm{~mm}, \triangle ; 0.5 \mathrm{~mm}$ 


\section{3.3 照射時の温度}

Table 1 に各温度での照射における水素生成量を示 す。実験範囲では水素生成量の温度による大きな変化は 見られなかったため,室温に近い $25^{\circ} \mathrm{C}$ 照射温度とした。

\section{3.4 周波数による効率の変化}

周波数はキャビテーションの様子に影響を及ほす重要 な因子の一つである。ソノルミネッンスの測定からも， 周波数が小さければラジカルなどの反応活性種の生成量 が減少し, 周波数が大きすぎるとキャビテーションバブ ルの成長，崩壊が十分にならないため，やはり反応活性 種の生成量が減少してしまうことが報告されている ${ }^{12)}$ 。 得られた Table 2 より, 周波数は 3 点の内, $200 \mathrm{KHz}$ （強

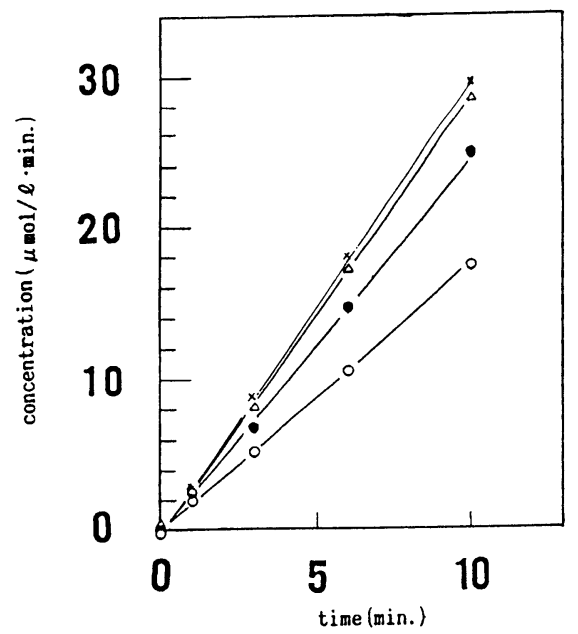

Fig. 3 Effect of content volume on formation of ferric ion in the ultrasonic irradiation of ferrous solution
$\bigcirc ; 125 \mathrm{~m} \ell$
$100 \mathrm{~m} \ell, \triangle ; 75 \mathrm{~m} \ell, \mathrm{X} ; 50 \mathrm{~m} \ell$

Table 1 Yields of hydrogen under various temperatures ${ }^{\text {a) }}$

\begin{tabular}{lll}
\hline $20^{\circ} \mathrm{C}$ & $25^{\circ} \mathrm{C}$ & $30^{\circ} \mathrm{C}$ \\
\hline 10.53 & 10.61 & 10.45 \\
\hline
\end{tabular}

a) $\mu \mathrm{mol} / \ell \cdot \min$.
度 $\left.6 \mathrm{~W} / \mathrm{cm}^{2}\right)$ が最適であった。

\section{3.5 照射超音波の強度}

超音波の強度もキャビテーションの生成に影響があ る。Fig. 4 から明らかなように，1１-DCA の濃度変化は 相対強度 4 付近からほとんど変わっていない。また超音 波の脱気作用により1,1-DCA が気相部分へ揮散し, 液 相の濃度が減少していた。このことより，照射強度 4 を 装置の最大出力とした。

\section{3.6 照射雰囲気による水素の生成量}

種々の雲囲気下での照射による水素生成量を Table 3 に示す。酸素および空気雲囲気の場合は，酸素濃度が高 いため, 式(2)に示すように酸素分子と水素ラジカルが, 水素ラジカル同士の再結合反応よりも速く反応するた

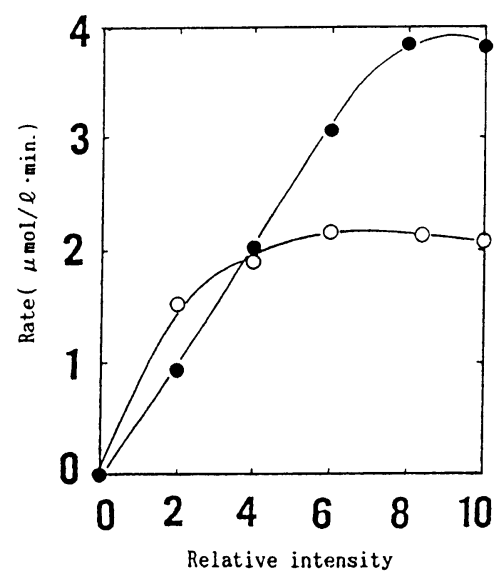

Fig. 4 Effect of ultrasound intensity on degradation rate of 1,1-DCA in the ultrasonic irradiation of aqueous solution under argon

$\bigcirc$; 1,1-DCA, ; chloride ion

Table 2 Yields of hydrogen in ultrasonic irradiation with various frequency ${ }^{\text {a) }}$

\begin{tabular}{lrcc}
\hline \multicolumn{2}{c}{$50 \mathrm{kHz}$} & $200 \mathrm{kHz}$ & $600 \mathrm{kHz}$ \\
\hline $6 \mathrm{~W}$ & 0.53 & 10.61 & 4.45 \\
\hline $4.8 \mathrm{~W}$ & 0.34 & 6.23 & 3.46 \\
\hline a) & $\mu \mathrm{mol} / \ell$ & $\cdot \mathrm{min}$.
\end{tabular}

Table 3 Yields of hydrogen under various gases ${ }^{\text {a) }}$

\begin{tabular}{lccccc}
\hline $\mathrm{Ar}$ & $\mathrm{He}$ & $\mathrm{N}_{2}$ & $\mathrm{~N}_{2} \mathrm{O}$ & $\mathrm{O}_{2}$ & air \\
\hline 10.61 & 4.42 & 0.0 & c) & c) \\
\hline a) $\mu \mathrm{mol} / \ell \cdot$ min., & & & \\
b) & & & & \\
failure of measurement, & & & &
\end{tabular}


め，水素は検出できなかった。

$$
\mathrm{H} \cdot+\mathrm{O}_{2} \rightarrow \mathrm{HO}_{2} \cdot
$$

ヘリウムの場合もへリウムと水素のピークが重なったた め，やはり水素の定量はできなかった。これを除くと， アルゴン雾囲気下で最大の水素生成量が得られた。また， アルゴンは熱伝導度, 比熱比, 溶解度が大きいため, キャ ビーテションバブルの温度も高く, 超音波照射に最も有 利であった ${ }^{13)}$ 。

\section{3. 7 硝酸の生成}

硝酸は䨌囲気に用いる気体によってキャビーテション バブル内の反応から生じたものである。空気雾囲気下の 場合には酸素と窒素の反応で, Fig. 5 に示すように超音 波照射によって, 硝酸および亜硝酸を生ずる。ほかの雾 囲気下の照射ではこれらは，ほとんど生成しなかった。

\section{3.8 振動子の性能評価}

インジゴカーミン水溶液の濃度は超音波照射時間に伴 い速やかに分解するため, 新しい振動子を用いて照射し

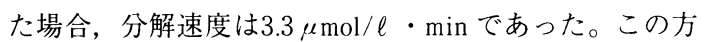
法による性能評価においては振動子は少なくとも6か月 間は劣化しなかった。

\section{4 結論}

用いる系に㧈ける超音波照射については底面が薄く， 照射溶液が少ないほど単位溶液量あたりのエネルギー吸 収量が大きくなるが，液面の高さが，半波長の整数倍で あるとき定常波が形成されることにより吸収効辦が良く なった。超音波照射による反応は, キャビーテションバ ブルの温度により支配されるため, 照射時の溶液の温度 は反応活性種の生成には影響を及ぼさなった。照射超

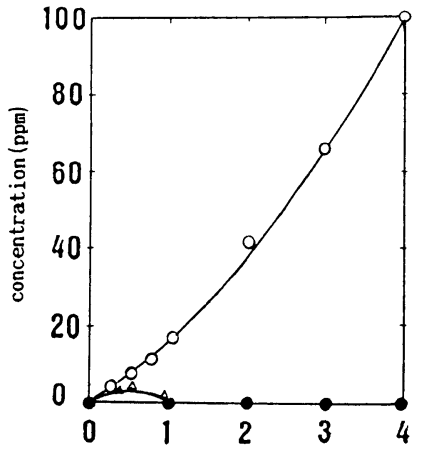

Fig. $5 \mathrm{NO}_{2}^{-}$and $\mathrm{NO}_{3}^{-}$ion formations in the ultrasonic irradiation of water under various gases

Nitrate ion. $\mathrm{O}$; under air, $\mathrm{O}$; under $\mathrm{Ar}, \mathrm{O}_{2}$, $\mathrm{N}_{2}, \mathrm{~N}_{2} \mathrm{O}$, He Nitrite ion. $\triangle$; under air
音波の周波数と強度は超音波照射により形成される 2 種 のキャビーテションバブルの割合に影響を及ほす。空気 䨌囲気下での照射では酸素と窒素の反応により亜硝酸と 硝酸が生成した。また，アルゴンの雾囲気下が最もキャ ビーテション生成に有利であることが分った。

\section{3. クロロエチレン類有機塩素化合物の超 音波分解}

得られた最適条件でクロロエチレン類水溶液の超音波 分解を行った。

\section{1 実験}

3. 1.1 試薬

トリクロロエチレン（以下は TCE と略記），テトラク ロロエチレン（以下はPCE と略記），1，1,1-トリクロロ エタン (以下は TCA と略記),$t$ ブチルアルコール,$n^{-}$ デカンは和光純薬工業製試薬特級を用いた。水は 2.2 . 1 に同じ。

\section{1 . 2 装置}

実験装置は2２２２２同じ。

\section{1.3 実験操作}

（1）試料水溶液の調製；照射容器に純水 $65 \mathrm{~g}$ を入れ，照 射雾囲気とする気体を40分間バブリングし, 所定量の有 機塩素化合物をマイクロシリンジで注入し，攪拌後，恒 温槽に45分間放置し, 試料の濃度を GC-ECDによって確 認した。tーブチルアルコールの添加は, アルゴン雾囲気 下の TCE 水溶液を調整する際，はじめに純水とともに, t-ブチルアルコールを TCEの1000倍モル量添加して調 製した。空気雲囲気下の照射に用いる試料は， $1 \ell$ の三 角フラスコに調整したものをそれぞれ用いた。

（2）超音波照射；照射容器に $10 \mathrm{ppm}$ の有機塩素化合物 水溶液を $65 \mathrm{~g}$ 入れ，10２0分間超音波照射を行った。サ ンプリングは 1 ～2 分抒きに $1.4 \mathrm{~m} \ell$ の試料溶液をガラス 製シリンジを用いて採取した。

採取した試料溶液を $10 \mathrm{~m} \ell$ の栓付試験管に入れ, $1.4 \mathrm{~m} \ell$ の $n$-デガンを加え, 振とうし, 有機塩素化合物を 抽出した後, $n$-デガン層の有機塩素化合物の濃度を GC-ECD で，水層の塩化物イオンおよび硝酸イオンの濃 度をイオンクロマトグラフでそれぞれ測定した。同時に 照射容器内の気体を有機塩素化合物は GC-ECD で, 水素, メタン, 一酸化炭素, 二酸化炭素は GC-TCD でそれぞれ 測定した。

\section{2 結果および検討}

3. 2. 1 クロロエチレン類の超音波分解

TCE，PCE，TCAの種々の雲囲気下での超音波照射に 
よる分解の様子を Fig. 6,7 に示す。いずれの化合物も アルゴン雾囲気下での分解が最も速く，10分間で $80 \%$ 以 上が分解された。これらの分解における, $\mathrm{OH}$ ラジカル の作用を確かめるため, TCEのアルゴン䨌囲気下の照 射の系に $\mathrm{OH}$ ラジカル捕捉剤である $t^{-7 ゙ チ ル ア ル コ ー ル ~}{ }^{14)}$ をTCEの1000倍モル量添加して分解を行った。Fig. 8 に 示すように分解量には捕捉剂の効果はほとんど見られな かった。さらに，三つの化合物が共存しても，それぞれ がほほ同じ速度で減少した。これらのことから, TCE, PCE, TCA の超音波照射による分解には, OH ラジカル との反応以外の反応, 即ち超音波照射によるキャビテー ションの内部拉よびその界面において，アルゴン雲囲気

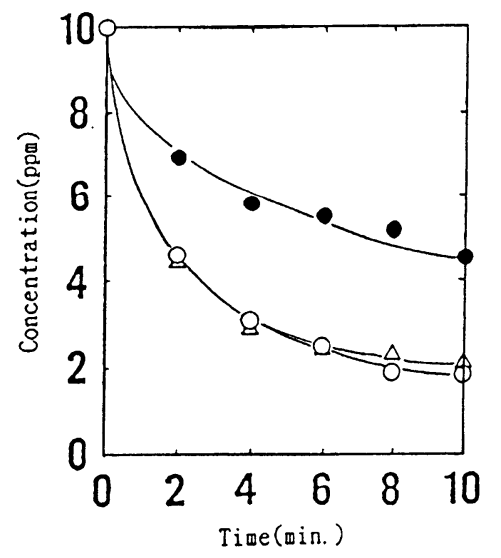

Fig. 6 Time-profiles of decomposition of chlorinated hydrocarbon in the ultrasonic irradiation of aqueous solution under air

O; TCE, O; PCE $\triangle$; TCA

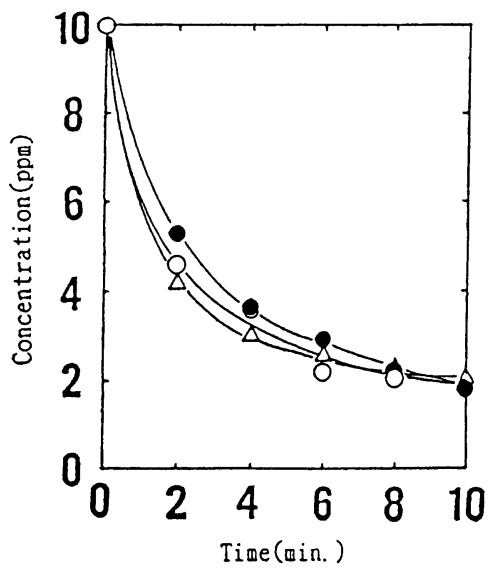

Fig. 7 Time-profiles of decomposition of chlorinated hydrocarbon in the ultrasonic irradiation of aqueous solution under argon

O; TCE, ; PCE $\triangle$; TCA
下では熱分解, 酸素および空気雲囲気下では燃焼反応が 起こっていると考えることができた。

\section{2.2 クロロエチレン類の超音波分解生成物}

Fig. 9 にTCEのアルゴン雲囲気下の照射における, TCE の分解生成物の様子を示す。分解生成物として塩 化物イオン, 一酸化炭素, 二酸化炭素, 水素, 極少量の メタン，エチレンが同定された。Table 4 に各化合物, 各条件における超音波照射による完全脱塩素化率, 無機 炭素転化率を示す。どの場合も超音波照射によって非常 に効率良く脱塩素化が達成されたことが分かる。

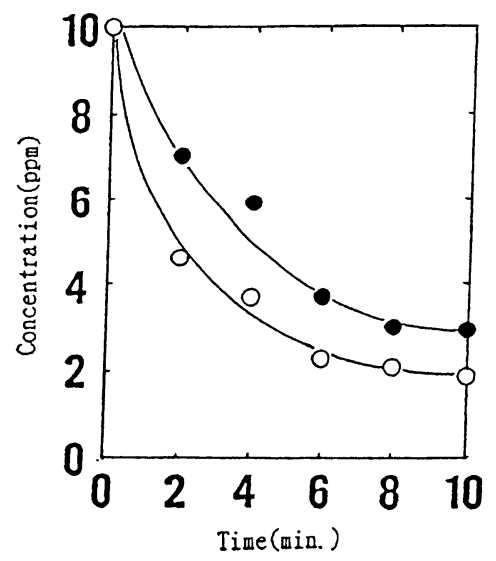

Fig. 8 Time-profiles of decomposition of trichloroethylene in the ultrasonic irradiation of aqueous solution added tert-butyl alcohol ; only TCE,

; added tert-butyl alcohol

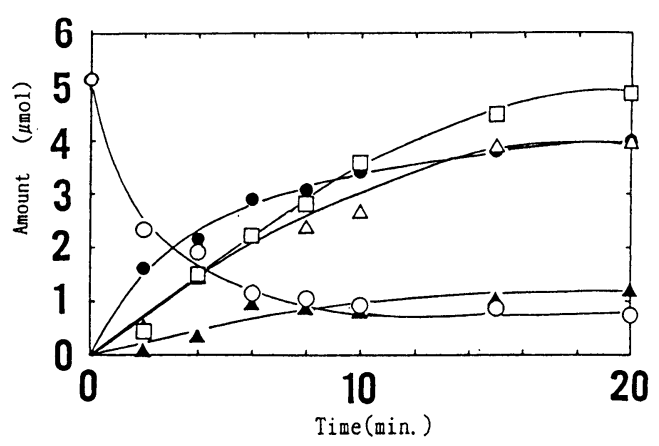

Fig. 9 Time-profiles of decomposition of trichloroethylene and product formation in the ultrasonic irradiation of aqueous solution under argon

$\bigcirc$; trichloroethylene, chloride ion $(\times 1 / 3)$ $\square$; hydrogen, $\triangle$; carbon monoxide, $\boldsymbol{\Delta}_{\text {; carbon }}$ dioxide 
Table 4 Dechlorination ratio and conversion ratio to inorganic carbon in the sonolysis

\begin{tabular}{|c|c|c|c|c|}
\hline \multirow{2}{*}{$\%$} & under & argon & under oxygen & under air \\
\hline & $\mathrm{Cl}^{\mathrm{a})}$ & $\mathrm{CO}^{\mathrm{b})}$ & $\mathrm{Cl}^{\mathrm{a})}$ & $\mathrm{Cl}^{\mathrm{a}}$ \\
\hline TCE & 91 & 81 & 85 & 83 \\
\hline PCE & 82 & 82 & 80 & 82 \\
\hline TCE & 87 & 73 & 81 & 82 \\
\hline
\end{tabular}

各条件における超音波照射による完全脱塩素化率，無機 炭素転化率を示す。どの場合も超音波照射によって非常 に効率良く脱塩素化が達成されたことが分かる。

\section{3 結論}

クロロエチレン類有機塩素化合物は，その水溶液への 超音波照射によって極わめて速やかに分解し，10分間の 照射で掠よそ80\%以上が分解した。この分解には，キャ ビテーションに大きな影響を及ほす照射時の雲囲気の影 響は少なく，キャビテーション内拈よびその界面の領域 で熱分解あるいは燃焼反応により分解していることが分 かる。分解の主生成物は, 塩化物イオンおよびCO, $\mathrm{CO}_{2}$ などの無機炭素であり, 微量の炭化水素も生成した。 完全脱塩素率は，ほとんどの場合 $80 \%$ 以上であった。本 実験では10ppm の試料について検討したが，分解速度は 有害化学物質濃度に 1 次反応であるので, さらに低濃度 または高濃度の対象についても分解率は変わらず，十分 に分解できるものと考えられる。

\section{謝 辞}

本研究は科学技術庁振興調整費 “協奏反応場の増幅制 御を利用した新材料創製に関する研究”の援助を受けて 行った。ここに深く感謝する。

\section{要 約}

超音波照射を用いた廃水処理過程では，処理装置およ び操作条件によって処理効果が異る。本研究では, 照射 容器, 照射温度, 超音波周波数㧍よび強度, 振動子の性 能, アルゴン, 空気, 酸素, 窒素, 亜酸化窒素, ヘリウ ムなどの照射雾囲気について諸因子の処理効果に及ほす 影響を検討した。得られた最適な条件下でクロロエチレ ン類の水溶液の分解を行った。初濃度 $10 \mathrm{ppm}$ のトリクロ ロエチレン，テトラクロロエチレン，1，1，1-トリクロロ エタンに対して10分間超音波照射すると，それぞれの有 機塩素化合物の $80 \%$ 以上が分解した。分解の主生成物は, 塩化物イオンと無機炭素 $\left(\mathrm{CO}\right.$ と $\left.\mathrm{CO}_{2}\right)$ であった。

\section{文 献}

1）(財関西産業公害防止センター,「トリクロロエチレ ン等有機塩素化合物使用実態調查報告書」, P.11 (1991)

2）環境庁環境化学物質研究会,「環境化学物質要覧」, 丸善 (1988)

3) Glaze, W.H., Kang, J.W. and Chapin, D.H.: Ozone, 9, 335 (1987)

4）矢崎哲夫，熊谷裕男：還元処理による有機塩素化合 物の除去 (第 2 報) 一鉄粉によるトリクロロエチ レンの処理 一, 工業用水，369，19-25（1989）

5）田中啓一：有機塩素化合物の処理方法，水処理技 術, 32, 61-65, 553 (1991)

6) Lage, G.B., Persons, F.Z. and Nassar, R.S.: Kinetics of the Depletion of Trichloroethene. Environ. Sci. Technol., 21, 366-370 (1987)

7）稲津晃司, 永田良雄, 前田泰昭：Decomposition of Chlorinated Hydrocarbous in Aqueous Solutions by Ultrasonic Irradiation. Chem. Lett., 57-60 (1993)

8) Anbar, M. and Pecht, M.: J. Phys. Chem. 40, 608 (1964)

9) Makino, K., Mossaba, M. and Riesz, P.: Chemical Effect of Ultrasound on Aqueous Solution. J. Phys. Chem., 87, 1369-1377 (1983)

10) Lorimer, J.P., et al., "Sonochemistry-The Use of Untrasound in Chemistry" Edited by Mason, T.J., Royal Society of Chemistry (1990)

11) Suslick, K.S., Flint, E.B. and Zakin, M.R.: Cavitation Thermometry Using Molecular and Continuum Sonoluminescence. J. Phys. Chem., 100, 6612-6619 (1996)

12）畑中信一, 辻内 亨, 小塚晃透, 三留秀人：Proc. 7th Annual Meeting of the Japan Society of Sonochemistry, 17 (1998)

13) Buttner, J., Gutierrez, M. and Henglein, A.: Sonolysis of Water-Methanol Mixtures. J. Phys. Chem. 95, 1528-1530 (1991)

14) Nagata, Y., Hirai, K., Bandow, H. and Maeda, Y.: 
Decomposition of Hydroxybenzoic and Humic Acids

Technol., 30, 1133-1138(1996)

in Water by Ultrasonic Irradiation. Environ. Sci. 